Janković, S., Popović, V., Rakić, S., Simić, D., Alkhammas, A. O., Rakić, R., Stanković, S. (2020): Influence of nutrition on productivity and chemical composition of Khorasan wheat - Triticum turgidum L. ssp. turanicum Jakubz. Agriculture and Forestry, 66 (4): 113-124.

DOI: 10.17707/AgricultForest.66.4.09

Snežana JANKOVIĆ, Vera POPOVIĆ, Sveto RAKIĆ, Divna SIMIĆ, Ayiman Omar ALKHAMMAS, Radojica RAKIĆ, Slađan STANKOVIĆ ${ }^{I}$

\title{
INFLUENCE OF NUTRITION ON PRODUCTIVITY AND CHEMICAL COMPOSITION OF KHORASAN WHEAT - Triticum turgidum L. ssp. turanicum Jakubz
}

\section{SUMMARY}

Khorasan wheat (Triticum turgidum L. ssp. turanicum Jakubz.) the white awn population is the optional type of a high-energy grain. This study aimed to examine the influence of plants' mineral nutrition on the chemical composition of Khorasan grain. The mineral diet used in the supplementary plant nutrition affected the total amount of dry matter and the chemical composition of wheat grains, increasing its nutritional value. At the time of harvest, Khorasan wheat grains contained $89.74 \%$ of dry matter, i.e. $10.26 \%$ of water, while in the variants with additional nutrition had less dry matter $86.90 \%$ and more water, $13.10 \%$, which indicates an extension of the vegetation period of plants in conditions of enhanced mineral nutrition. Mineral nutrition, which primarily increased the amount of nitrogen, statistically significantly affected protein synthesis in plants. Khorasan wheat grains had $14.94 \%$ of total proteins in the control and $15.2 \%$ in variants with NPP nutrition. Plant nutrition did not have a greater impact on the synthesis of oils in the grains, starch, NFE, and mineral salts content. The supplementary nutrition affected the total amount of dry matter and chemical composition of wheat grain increasing its nutritional value.

Keywords: Khorasan wheat, supplementary mineral nutrition, the chemical composition of grain

\section{INTRODUCTION}

Khorasan wheat (Triticum turgidum L. ssp. turanicum Jakubz.) has been grown thousands of years ago in the area of ancient civilizations, the Middle East, and ancient Egypt. This ancient type of wheat was cultivated in the area of Big Khorasan (Northeastern Iran area of and neighboring countries) 6,000 years ago.

\footnotetext{
${ }^{1}$ Snežana Janković, (corresponding author: sjankovic@ipn.bg.ac.rs; vera.popovic@ifvcns.ns.ac.rs); Divna Simić, Slađan Stanković, IPN Institute of Applied Sciences, Belgrade, SERBIA

Vera Popović, Institute of Field and Vegetable Crops, Institute of National Importance for the Republic of Serbia, Maksima Gorkog 30, Novi Sad, SERBIA

Sveto Rakić, Radojica Rakić, University of Belgrade, Faculty of Agriculture, Nemanjina 6, Zemun Belgrade, SERBIA

Notes: The authors declare that they have no conflicts of interest. Authorship Form signed online. 
Khorasan wheat was most likely formed by the spontaneous crossing of durum and field wheat. It is very close to durum wheat (AABB genome) in terms of genetic and morphological characteristics. In terms of nutritional value, it is superior to soft wheat and is a high-energy grain. Khorasan wheat (kamut) has very large grains of great nutritional value. Khorasan wheat is richer in oils, vitamins, and mineral salts. The increased content of monosaccharides gives the grain a sweet taste, so kamut is also called "sweet wheat". The flour obtained by grinding of these grains is added to wheat grains, in different proportions, for making pasta and bakery products of higher nutritional and energy value. These food products are suitable for the diet of more physically active people and people allergic to gluten because it contains significantly less gluten than wheat grains according to the research by the International Association for Allergies in Food (IFAA) (Ikanović et al., 2014).

In the diet of domestic animals, bran is used as a concentrated fodder, straw serves as a mat or as a raw material in further processing. Compared to soft wheat, kamut is more tolerant to drought and pests and has a higher coefficient of utilization of plant assimilates from the soil. Good production and biological properties have included this wheat in the system of organic farming, and the growing demand for food products has also affected the increase in the areas under this crop. In terms of average grain yields, Khorasan wheat is competitive, so it can be interesting for the system of conventional agriculture (Glamočlija et al., 2015; Ikanović, Popović, 2020).

The grain of this wheat is curved in the middle and larger than the classic varieties of wheat. Khorasan wheat is used to make good bread, toast, cakes, snacks, and other bakery products. Although lately, this ancient cereal has been attracting more and more attention in Serbian area little who is informed about it. In Western countries, Khorasan has become an unavoidable part of the daily menu, especially because it suits people who are sensitive to gluten. Kamut contains gluten, which is well tolerated by people who are sensitive to gluten from common wheat. Studies have shown that a large percentage of sensitivities be can reduced sensitivity consuming Khorasan wheat. Kamut grain is valued by consumers as a grain with high energy values, easy digestion, nutty taste, and firm structure. It contains more proteins, amino acids, selenium, and vitamin $\mathrm{E}$ than today's wheat varieties and contains essential minerals such as magnesium and zinc. It contains essential vitamins $\mathrm{E}$ and $\mathrm{A}$, and is a good source of $\mathrm{B}$ vitamins. Also, it contains calcium, iron, magnesium, potassium, sodium, and zinc. Kamut provides fibber, carbohydrates, and essential macronutrients. Proteins play a significant role in strengthening tissues, and also help in oxygen transport, while fibbers lower cholesterol and affect the maintenance of the healthy digestive system. Kamut is a source of minerals selenium and manganese, which have an antioxidant effect. The grains consist of water, organic, and mineral substances. Among organic substances, the main ingredients are nitrogen-free extractives (NFE) i.e. starch and partially sugars, and their content varies from $50-70 \%$ and even more, and especially in hulled rice up to $75 \%$, 
followed by crude proteins, which range from 8-18\% and over it, and cellulose from $2-11 \%$. The water content in the dry grain is around 14-15\%. Of the nitrogen-free extractives, the grains contain the starch mostly, which is found in the endosperm and makes up about $80 \%$ of all carbohydrates. The rest falls on sugars, primarily cane sugar, which is primarily found in germ, about $1.5 \%$ of the weight of the grain. There is no starch in the germ. The oil content in the grain of cereals ranges from 2-4\%. The oil is found primarily in germ, about $14 \%$ in wheat, $12.4 \%$ in rye, up to $26 \%$ in oats, and $20 \%$ in millet. Minerals - ash - are found mainly in the grain husk. In complex grinding, most of the minerals go into the bran, and the finer the grind is done, the less mineral matter exists in the flour. The main component of cereals ash is phosphorus, about $50 \%$, then potassium, about $30 \%$, magnesium, about $12 \%$, and there is little calcium, about $2.8 \%$. Cellulose is also found mostly in the shells of grains, and especially in husky forms and cell walls. The content of cellulose is higher in small grains than in large ones. In addition to the above ingredients, the grain also contains enzymes and vitamins. Enzymes play a significant role in the germination of grains, and in the decomposition of nutrients into an affordable form for germination. The main enzymes in grain are diastase (dissolves starch and sugar), lipase (fat), a group of proteolytic enzymes that break down proteins and oxidative enzymes peroxidase, etc. Cereal grain vitamins contain a vitamin complex: carotene as a source of vitamin A, then in small amounts B1, B2, E, K, and PP. Vitamins are mostly found in the germ (Glamočlija et al., 2015; 2017).

As this wheat species originates from the arid areas of Central Asia, khorasan wheat shows greater tolerance to abiotic stress caused by drought, which indicates possible directions of regionalization in Serbia (Alkhammas, 2017). The production year has the great impact on wheat productivity (Malešević et al., 2005; Popović, 2010; Filipović and Ugrenović, 2010; Ugrenović, 2013; Jankovic et al., 2015; Lakić et al., 2015; Ugrenović et al., 2018; Terzić et al., 2019; Rajičić et al., 2020). This study aimed to determine the effect of $\mathrm{t}$ supplementary nutrition on the productivity and chemical composition of wheat grains.

\section{MATERIAL AND METHODS}

The subject of the study was the population of khorasan white awn wheat, optional type. The influence of supplementary mineral nutrition of plants on the chemical composition of wheat grains was investigated. Experimental field micro-experiments were performed in 2015/2016, in the Danube region, on chernozem-type soil, by the method of a random block system in four replications. The size of the experimental plots was $6 \mathrm{~m}^{2}$. The experiments were performed in three dietary variants: control (without mineral nutrients) and NPK 72:45:45 and NPK 99:45:45. Mineral nutrients NPK 15:15:15 were introduced with pre-sowing preparation in the amount of $300 \mathrm{~kg} \mathrm{ha}^{-1}$, and CAN in February by fertilizing crops. In the second variant, $100 \mathrm{~kg} \mathrm{ha}^{-1} \mathrm{CAN}$ was used, and in the third variant $200 \mathrm{~kg} \mathrm{ha}^{-1}$. After the harvest, the seeds were taken for chemical 
analysis (Glamočlija et al., 2017; Alkhammas, 2017). The chemical composition of the grain was tested in the Laboratory for Pharmacognosy of the Faculty of Pharmacy in Belgrade. The analyzes determined: the amount of starch, total proteins, cellulose, total lipids, mineral salts, and the amount of water (dry matter). Starch, oils, and mineral salts were determined using the method developed by Kaluđerski and Filipović (1998). To determine the amount of starch polarimeter a CARL ZEISS $24 / 60 \mathrm{~Hz}$ with a specific rotation angle of $181.3^{\circ}$ was used. The content of total proteins was determined by the Kjedahl method and converted by a factor of 6.25 (ISO 20483:2006). Total cellulose was determined by the Veender method using the Fibertec 2010 system. All examined parameters were analyzed using the statistical package Statsoft 12, ANOVA, and are presented in Tables and Figures.

\section{Meteorological conditions}

The examined production year 2015/2016 was favorable for the production of khorasan wheat. The total amount of precipitation as well as the average temperature during the vegetation period (total $638 \mathrm{~mm}$ and $11.7^{\circ} \mathrm{C}$ (in vegetative period $510 \mathrm{~mm}$ and $8.7^{\circ} \mathrm{C}$,) respectively - were lower than the multi-year average of these parameters (total year $691.0 \mathrm{~mm}$ and $2.4^{\circ} \mathrm{C}$, respectively (in vegetative period $518 \mathrm{~mm}$ and $\left.7.9^{\circ} \mathrm{C}\right)$ ), Figure 1.

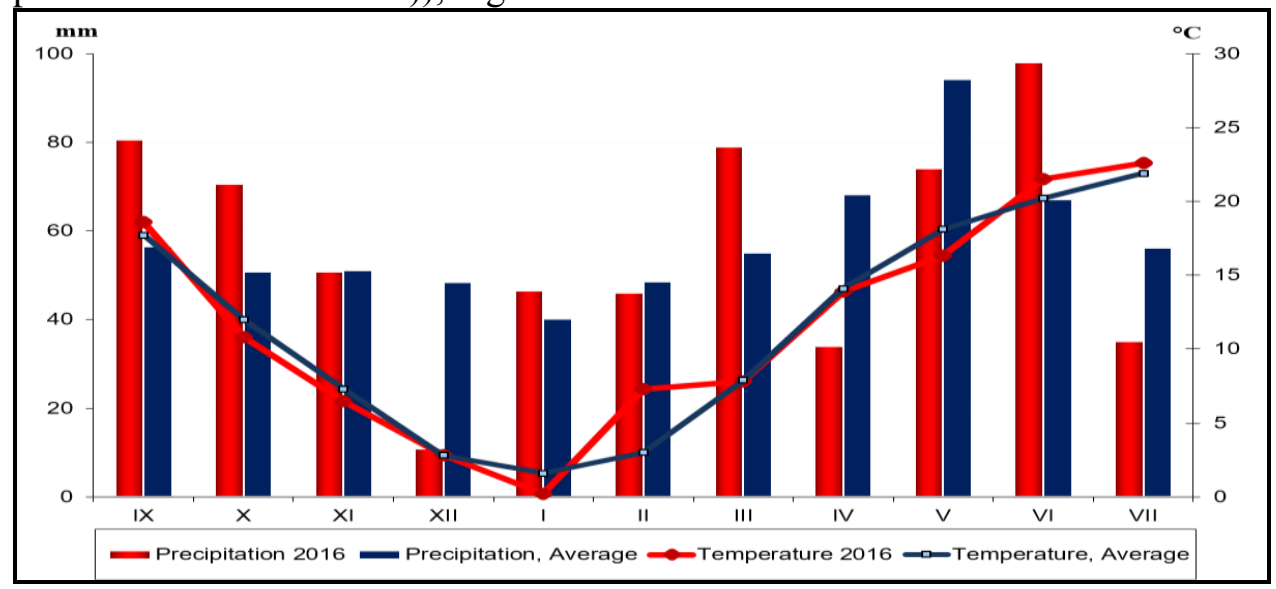

Figure 1. Temperature and precipitation of vegetation period of khorasan wheat

An temperature conditions with mild winters, moderately warm springs, and warm summer months were favorable for Khorasan wheat production.

\section{RESULTS AND DISCUSSION}

Productive characteristics of plant mass, number of spikelets, spike mass, grain mass, and harvest index are shown in Table 1. All examined factors varied and were statistically significantly higher for productive traits and qualitative traits (protein and cellulose content), although values of other tested quality 
parameters, in variants with supplementary nutrition, were higher compared to the control variant, but the difference was not significant (Tables 1-3).

The great influence of nitrogen on the productivity of khorasan wheat plants was confirmed in the researches of Glamočlija et al. (2015 and 2017) and Alkhammas (2017). The results of these researches indicated that the use of a smaller amount of nitrogen significantly increased the yield parameters. The highest values were achieved with a larger amount of nitrogen. The mass of plants varied from 3.2-3.8 g, the number of spikelets from 21-26, the mass of spikelets from 1.5-1.7 g, grain yield per plant from 1.1-1.81 g, and the harvest index from 35-49\%, (Table 1, Figures 2 and 3 ).

Table 1. Yield parameters of khorasan wheat

\begin{tabular}{|c|c|c|c|c|c|}
\hline Parameter & $\begin{array}{c}\text { Plant mass } \\
(\mathbf{g})\end{array}$ & $\begin{array}{c}\text { Number of } \\
\text { spikelets }\end{array}$ & $\begin{array}{c}\text { Spikelet } \\
\text { mass } \\
\mathbf{( g )}\end{array}$ & $\begin{array}{c}\text { Grain mass } \\
(\mathbf{g})\end{array}$ & $\begin{array}{c}\text { Harvest } \\
\text { index } \\
(\mathbf{\%})\end{array}$ \\
\hline I - Control & $3.20 \pm 0.15$ & $21 \pm 0.10$ & $1.5 \pm 0.13$ & $1.10 \pm 0.11$ & $35 \pm 2.15$ \\
\hline II & $3.50 \pm 0.11$ & $25 \pm 0.12$ & $1.6 \pm 0.15$ & $1.70 \pm 0.12$ & $49 \pm 2.11$ \\
\hline III & $3.80 \pm 0,12$ & $26 \pm 0.13$ & $1.7 \pm 0.12$ & $1.81 \pm 0.15$ & $48 \pm 1.16$ \\
\hline Average & $3.5 \pm 0.27$ & $24 \pm 0.25$ & $1.61 \pm 0.14$ & $1.53 \pm 0.35$ & $44 \pm 6.92$ \\
\hline
\end{tabular}

\begin{tabular}{|l|c|c|c|c|c|c|}
\hline \multicolumn{2}{|l|}{ Parameter } & $\begin{array}{c}\text { Plant } \\
\text { mass* }\end{array}$ & $\begin{array}{c}\text { No. of } \\
\text { spikelets* }\end{array}$ & $\begin{array}{c}\text { Spikelet } \\
\text { mass* }^{*}\end{array}$ & $\begin{array}{l}\text { Grain } \\
\text { mass* }\end{array}$ & $\begin{array}{l}\text { Harvest } \\
\text { index }\end{array}$ \\
\hline \multirow{2}{*}{ LSD } & 0.5 & 0.212 & 0.210 & 0.209 & 0.199 & 3.461 \\
\cline { 2 - 7 } & 0.1 & 0.303 & 0.302 & 0.303 & 0.303 & 5.24 \\
\hline
\end{tabular}

Mineral nutrients affected the total amount of dry matter and the chemical composition of khorasan wheat grains, increasing its nutritional value (Table 2).

Table 2. Chemical composition of khorasan wheat grain (\%)

\begin{tabular}{|c|c|c|c|c|c|c|c|}
\hline NPK* & DM & PC & OC & Starch & Cellulose & NFE & MS \\
\hline I & $89.74 \pm 1.09$ & $14.94 \pm 0.43$ & $22.4 \pm 0.20$ & $61.49 \pm 1,25$ & $38.23 \pm 0.25$ & $18.34 \pm 0.25$ & $14.82 \pm 0.05$ \\
\hline II & $86.87 \pm 0.13$ & $15.17 \pm 0.05$ & $23.1 \pm 0.62$ & $67.82 \pm 1,15$ & $39.10 \pm 0.11$ & $18.35 \pm 0.55$ & $14.73 \pm 0.35$ \\
\hline III & $86.90 \pm 0.15$ & $15.20 \pm 0.20$ & $22.7 \pm 0.15$ & $67.90 \pm 1,10$ & $38.71 \pm 0.12$ & $18.31 \pm 0.25$ & $15.76 \pm 1.71$ \\
\hline Average & $\mathbf{8 7 . 8 4} \pm 0.10$ & $\mathbf{1 5 . 1 4} \pm 0.43$ & $\mathbf{2 2 . 7} \pm 0.15$ & $\mathbf{6 5 . 7 4} \pm 1,95$ & $\mathbf{3 8 . 6 8} \pm 0.45$ & $\mathbf{1 8 . 3 4} \pm 0.43$ & $\mathbf{1 5 . 1 0} \pm 1.11$ \\
\hline
\end{tabular}

*NPP-plant nutrition, DM-dry matter, PC-protein content, OC-oil content, NFE-nitrogen free extractives, MS-mineral salts

\begin{tabular}{|l|c|c|c|c|c|c|c|c|}
\hline \multicolumn{2}{|c|}{ Parameter } & DM & PC* & OC & Starch & Cellulose $^{*}$ & NFE & MS \\
\hline \multirow{2}{*}{ LSD } & 0.5 & 1.267 & 0.347 & 0.765 & 40.655 & 0.033 & 0.079 & 2.010 \\
\cline { 2 - 9 } & 0.1 & 1.920 & 0.525 & 1.159 & 61.589 & 0.499 & 0.119 & 3.044 \\
\hline
\end{tabular}

In the control variant, kamut grains had $89.74 \%$ of dry matter $(10.26 \%$ of water), while in the variants with NPP mineral nutrients they had less dry matter $86.90 \%$ (13.10\% of water), which indicates the extension of the vegetation period of plants in conditions of enhanced mineral nutrition (Alkhammas, 2017). Similar 
results were obtained by Janković et al. (2011) studying the influence of nitrogen on the yield and grain quality of barley, i.e. wheat and oats by Rakić et al. (2012a and 2012b). Mineral nutrients, that primarily increased quantity of nitrogen, had a positive effect on protein synthesis in plants.

Average protein content was $15.14 \%$. Khorasan wheat grains had $14.94 \%$ of total proteins in control, and $15.20 \%$ in variants with NPK nutrition, that is $4.46 \%$ more (Table 2, Figure 4). Plant nutrition did not have a greater influence on the oil synthesis in the grains, so the difference between the control variant $(22.4 \%)$ and the variant with NPK mineral nutrients $(22.7 \%)$ was $15.68 \%$. This difference is the result of bouncing and better-poured grains in plants in the NPK mineral nutrition system.

A statistically significant difference between variants (control, and plant nutrition) was in the amount of cellulose. The amount of digestible cellulose in kamut grains grown without supplementary nutrition (38.23\%) was statistically significantly lower, by $0.9 \%$, compared to the variants with NPK mineral nutrients $(39,10 \%)$, (Table 2, Figure 4).

Khorasan wheat grains in control had less NFE than in supplementary plant nutrition variants. Also, the content of mineral salts in the grains of control plants was lower compared to the variants of supplementary nutrition, which is a consequence of less photosynthetic activity and faster maturation of plants.

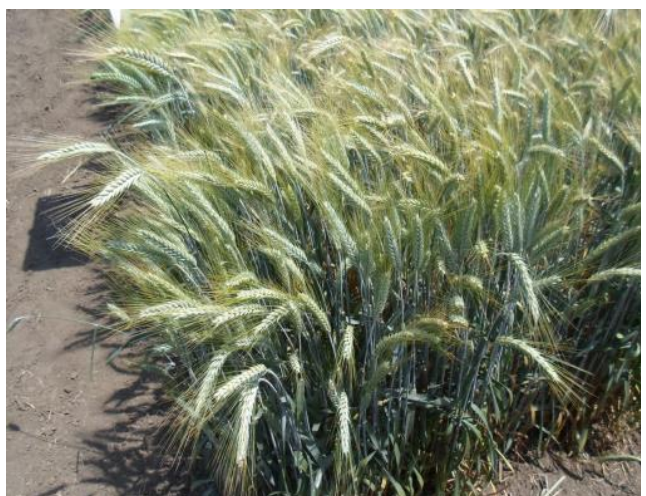

(a)

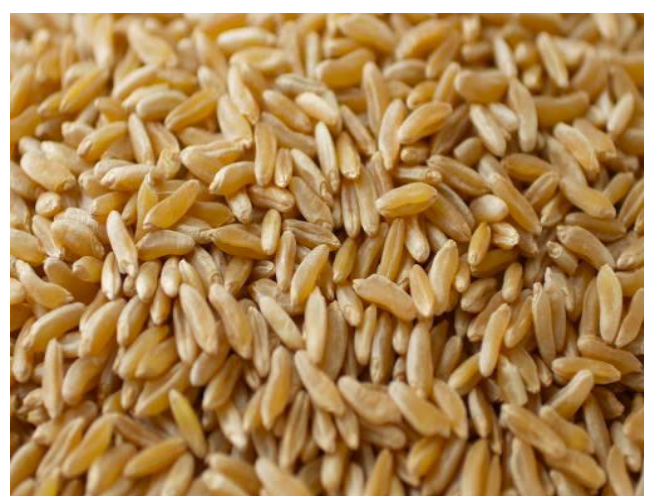

(b)

Picture 1. Khorasan wheat plants in the experimental field (a), khorasan wheat grains (b)

The identification of those biological processes that act as markers in tropical wheat is essential for its cultivation across new agricultural frontiers, the promotion of new farming practices, and the attainment of higher yields (Ferreira et al., 2019). The ecological exam is necessary to clarify the true adaptability and suitability of winter wheat variety for regional conditions (Nazarenko et al., 2019). 


\section{Mass of grain $=$ Distance Weighted Least Squares}

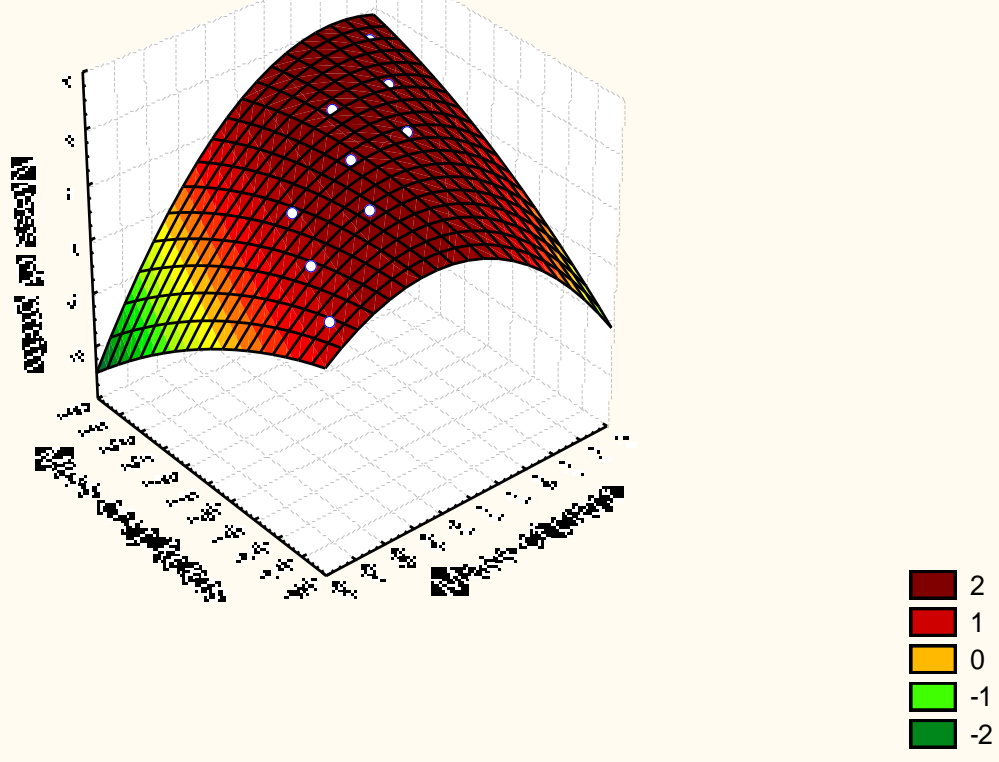

Figure 2. 3D Surface plot for the mass of grain, the mass of spikelets and the mass of plant

Mineral salts $=$ Distance Weighted Least Squares

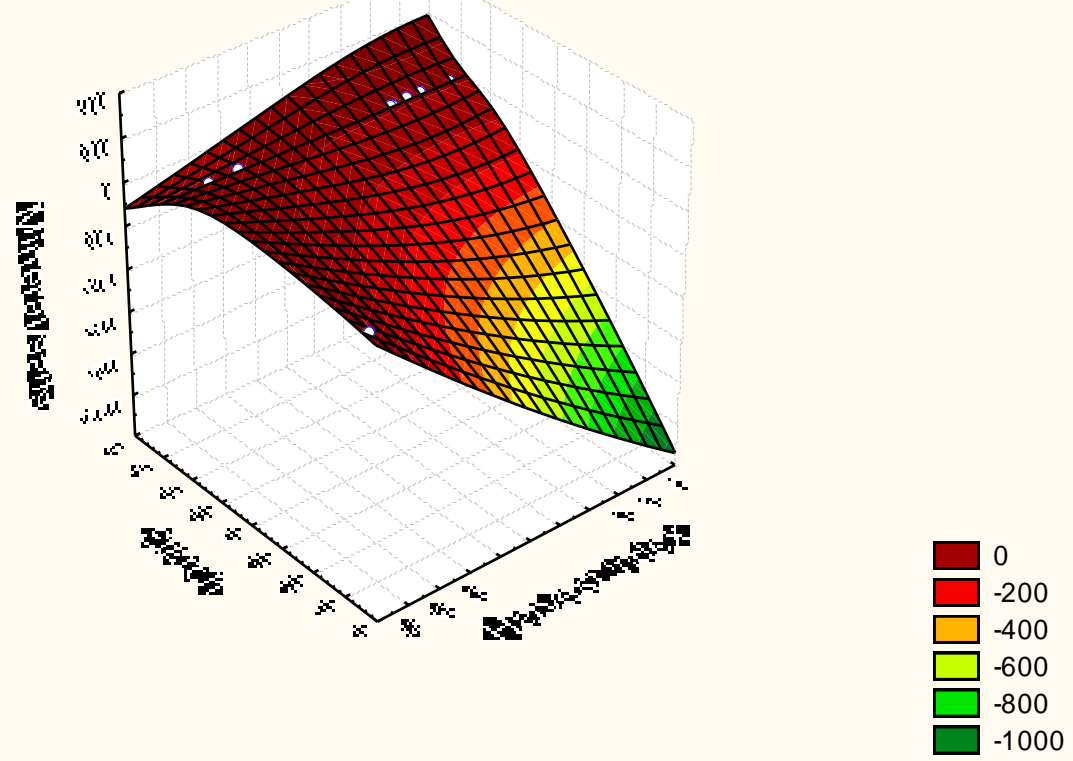

Figure 3. 3D Surface plot for harvest index, starch and mineral salts 


\section{Cellulose $=$ Distance Weighted Least Squares}

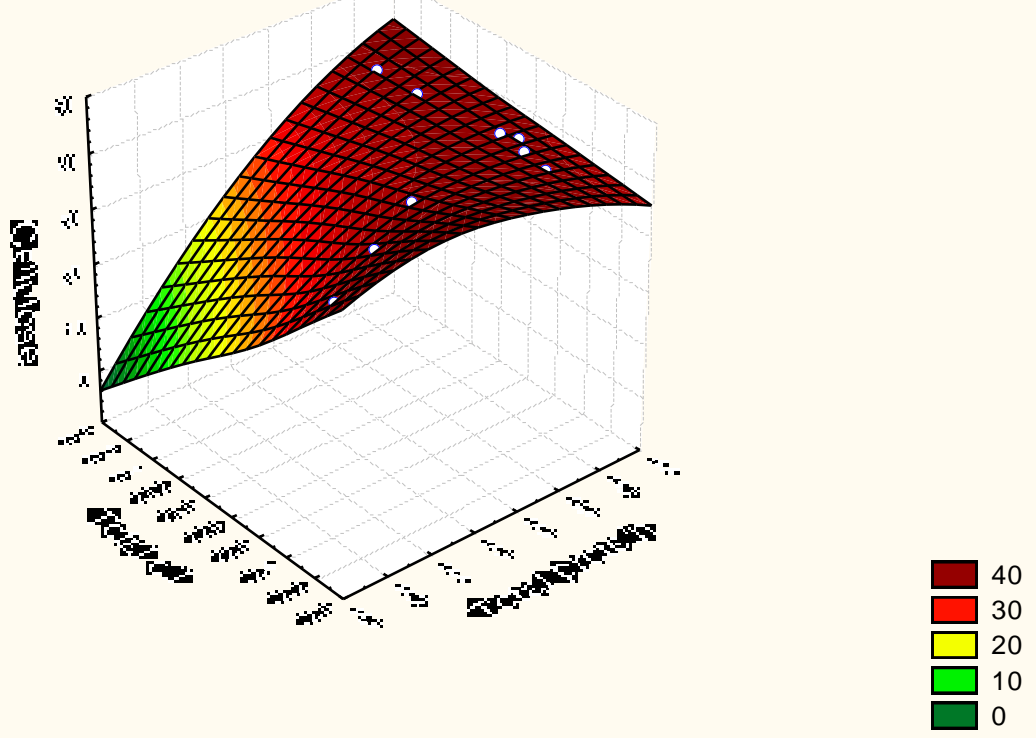

Figure 4. 3D Surface plot for cellulose, total oil, and total protein content

Analysis of the total amounts of polyphenols and antioxidant values of khorasan wheat grain showed that its grain has a higher values use (Table 3 ).

In the tested khorasan wheat grain samples, the NPP variants showed that the content of total polyphenols was in the range of $10.50-10.85 \mathrm{mg} \mathrm{GA} / \mathrm{g}$, which is on average higher than in the control samples $(9.44 \mathrm{mg} \mathrm{GA} / \mathrm{g})$. The total antioxidant capacity of the tested extracts (FRAP value) was in the range of $39.48-45.61 \mu \mathrm{mol} \mathrm{Fe} \mathrm{Fe}^{2+} / \mathrm{g}$ of extract. The FRAP values of the samples in the variant with NPP were higher than the FRAP values of the control (Table 3).

Table 3. Total polyphenols and antioxidant activity of khorasan wheat grains

\begin{tabular}{|c|c|c|c|}
\hline Variant & $\begin{array}{c}\text { Total polyphenols } \\
(\mathrm{mg} \mathrm{GA} / \mathrm{g})\end{array}$ & $\begin{array}{c}\mathrm{FRAP}^{\mathrm{b}} \\
\left(\mu \mathrm{mol} \mathrm{Fe}^{2+} / \mathrm{g}\right)\end{array}$ & $\begin{array}{c}\mathrm{DPPH}^{\mathrm{c}} \\
(\mathrm{mg} / \mathrm{ml})\end{array}$ \\
\hline I Control & $9.44 \pm 0.60$ & $39.48 \pm 4.12$ & $1.78 \pm 0.77$ \\
\hline II Variant* & $10.50 \pm 0.69$ & $44.12 \pm 2.57$ & $1.81 \pm 0.92$ \\
\hline III Variant & $10.85 \pm 0.75$ & $45.61 \pm 6.45$ & $1.76 \pm 0.14$ \\
\hline Average & $10.16 \pm 0.73$ & $42.87 \pm 3.20$ & $1.76 \pm 0.05$ \\
\hline
\end{tabular}

$\mathrm{NPP}^{*}$-supplement nutrition, ${ }^{a}$ total polyphenols (expressed as mg of gallic acid-GA per gram of dry ethanol extract); ${ }^{b}$ total antioxidant capacity in $\mu$ mol $\mathrm{Fe}^{2+}$ per gram of dry extract, ${ }^{\mathrm{c}}$ concentration of investigated extract that neutralizes $50 \%$ of free DPPH radicals (SC50) in $\mathrm{mg} / \mathrm{ml}$

The reactivity of potential antioxidants to the stable DPPH radical was measured by the DPPH test, and the concentrations of the extracts that neutralized $50 \%$ of the DPPH radicals were in the range of $1.76-1.81 \mathrm{mg} / \mathrm{ml}$. These results 
are consistent with some previous results of anti-DPPH activity studies of different wheat cultivars (SC50 0.6-7.1 mg/ml) (Yu et al., 2002; Alkhammas, 2017). As with the FRAP test results, there was no significant difference in antiDPPH activity between the tested samples in the DPPH test. The shown antioxidant activity depended on the content, but also on the type of polyphenolic compounds in the tested samples.

The growing interest in ancient grains appears in recent literature, because of their nutritional and health properties, and especially on KAMUT® khorasan wheat. Any khorasan wheat sold under the KAMUT ${ }^{\circledR}$ brand must follow several quality specifications related both to the nutritional characteristics and growing conditions (i.e. the grain must be grown organically) (Bondet et al., 1997; Quinn, 1999). Some studies demonstrated that KAMUT ${ }^{\circledR}$ khorasan wheat has the high carotenoids content (Abdel-Aal et al., 2007) and a unique nutraceutical value for its peculiar content in bioactive phytochemicals (Dinelli et al., 2009).

Furthermore, KAMUT® khorasan wheat is rich in selenium. It has been demonstrated that selenium content in KAMUT ${ }^{\circledR}$ khorasan bread was ten-fold higher than in modern durum bread (Piergiovanni et al., 2009; Gianotti et al. 2011; Benedetti et al., 2012). Selenium acts in the active site of several enzymes involved in cellular protection from oxidative damage, such as glutathione peroxidase (Xia et al., 2007) and other selenoproteins.

\section{CONCLUSIONS}

The quality, i.e. the nutritional value of khorasan wheat grains is the most important characteristic of this real grain, which distinguishes it from the group of other species of the genus Triticum. Analyses of the amounts of the most important nutrients: total proteins, starch, sugar, digestible cellulose, and mineral salts have shown that this wheat grown in the agroecological conditions of the Danube region has a great nutritional value. The amount of these substances was mostly influenced by the enhanced mineral nutrition of plants, so that their increased values justified additional investments in NPP mineral nutrients, especially the protein and cellulose content.

Analysis of the total amounts of polyphenols and antioxidant values of khorasan wheat grains showed that its grain has a higher use value compared to grains of other species of the genus Triticum. The obtained results of the content of total polyphenols, FRAP, and DPPH test showed higher values in the samples with applied NPK fertilizers compared to the control.

\section{ACKNOWLEDGMENTS}

This study was supported by the Ministry of Education, Science and Technological Development of the Republic of Serbia, and was created as a result of the projects: 451-03-68/2020-14/ 200045 and 200032 and bilateral project (Montenegro and Serbia; 2019-2020): Alternative cereals and oil crops as a source of healthcare food and an important raw material for the production of biofuel; and FAO Project (2020-2022): Redesigning the exploitation of small 
grains genetic resources towards increased sustainability of grain-value chain and improved farmers' livelihoods in Serbia and Bulgaria - GRAINEFIT.

\section{REFERENCES}

Abdel-Aalel, S. M., Young, J. C., Rabalski, I, Hucl, P., Fregeau-Reid, J. (2007): Identification and quantification of seed carotenoids in selected wheat species. J. Agric. Food Chem., 55: 787-794, DOI: 10.1021/jf062764p.

Alkhammas, A. O. (2017): Uticaj agroekoloških i zemljišnih uslova Podunavlja i Posavine na morfološke i proizvodne osobine korasan pšenice i mogućnost introdukcije u Libiji. Doktorska disertacija, Univerzitet Singidunum, Beograd, Fakultet za primenjenu ekologiju, Futura.

Benedetti, S., Primiterra, M., Tagliamonte, M. C., Carnevali, A., Gianotti, A., Bordoni. A., Canestrari, F. (2012): Counteraction of oxidative damage by an ancient grain (KAMUT brand khorasan wheat). Nutrition, 4: 436-41.

Bondet, V., Brand-Williams, W., Berset, C. (1997): Kinetics and Mechanisms of Antioxidant Activity using the DPPH Free Radical Method. LWTFood Science and Technology. 30: 609-615.

Dinelli, G., Segura Carretero, A., Di Silvestro, R., Marotti, I, Fu, S., Benedettelli, S. (2009): Determination of phenolic compounds in modern and old varieties of durum wheat using liquid chromatography coupled with time-of-flight mass spectrometry. J. Chromatogr. A., 1216: 7229 7240, DOI: 10.1016/j.chroma.2009.08.041.

Ferreira, M. H., Rocha, B. H., Silva, G. H., Macedo, W. R. (2019):

Multivariate analysis for wheat genotypes cultivated in Brazilian Savanna (Cerrado). Agriculture and Forestry, 65 (4): 183-192, DOI:10.17707/AgricultForest.65.4.16

Filipović, V., Ugrenović, V. (2010): Biološka raznolikost organske proizvodnje u funkciji očuvanja biodiverziteta. Četvrti forum o organskoj proizvodnji. Centar za organsku proizvodnju, Selenča, pp. 44-46.

Gianotti, A., Danesi, F., Verardo, V., Serrazanetti, D.I., Valli, V., Russo, A., et al. (2011): Role of whole grain in the in vivo protection from oxidative stress. Front Biosci, 16: 1609-1618, DOI: 10.2741/3808.

Glamočlija, Đ., Janković, S., Kuzevski, J., Đurić, N., Alkhammas, A.O., Glamočlija, N., Maksimović, J. (2017): Uticaj povećanih količina azota i tipa zemljišta na morfološke i proizvodne osobine korasan pšenice. XXXI Savetovanje agronoma, veterinara, tehnologa i agroekonomista Instituta PKB Agroekonomik, Padinska Skela, Beograd. 23 (1-2): 61-70.

Glamočlija, Đ., Janković, S., Popović, M. V., Kuzevski, J., Filipović, V., Ugrenović, V. (2015): Alternatively crop plants in conventional and organic growing systems. Monograph, Belgrade, ISBN 978-86-81689$32-5 ; 1-355$ 
Ikanović, J., Popović V. (2020): Organic plant production. Book., University of Banja Luka, Faculty of Agriculture /Organska biljna proizvodnja, Knjiga, Serbian/ Banja Luka, 1-235.

Ikanović, J., Popović, V., Janković, S., Živanović, Lj., Rakić, S., Dončić D. (2014): Khorasan wheat population researching in the minimum tillage conditions. Genetika, 46 (1): 105-115.

Jankovic, S., Glamoclija, Dj. Maletic, R., Rakić, S., Hristov, N. Ikanovic, J. (2011): Effects of nitrogen fertilization on yield and grain quality in malting barley. African Journal of Biotechnology, 10 (84): 19534-19541.

Jankovic, S., Popovic, V., Ikanovic, J., Rakic, S., Pavlovic, S., Ugrenovic, V., Simic, D., Doncic, D. (2015): Morphological and productive traits of spelt wheat - Triticum spelta L., Agriculture and Forestry, Podgorica, 1 (61): $173-182$.

Kaluđerski, G., Filipović N. (1998): Methods of analysis grain quality. Novi Sad: University of Novi Sad.

Lakić Ž., Glamočlija Đ., Kondić, D., Popović M. V., Pavlović S. (2015): Fodder plants and cereals in the function of protecting the soil from degradation. /Krmne biljke i žita u funkciji zaštite zemljišta od degradacije. Monograph. Banja Luka. 1-405.

Malešević, M., Crnobarac, J., Kastori, R. (2005): Primena azotnih đubriva i njihov uticaj na prinos i kvalitet proizvoda. In: „Azot“ (Kastori Rudolf ed.), Naučni institut za ratarstvo i povrtarstvo. Novi Sa , pp. 231-261

Nazarenko, M., Mykolenko, S., Chernysky, V. (2019): Modern Ukrainian winter wheat varieties grain productivity and quality at the ecological exam. Agriculture and Forestry, 65 (1): 127-136, DOI:10.17707/AgricultForest.65.1.13

Piergiovanni, A. R., Simeone, R., Pasqualone, A. (2009): Composition of whole and refined meals of Kamut under southern Italian conditions. In: "Chemical engineering transactions" (Ed. Pierucci). AIDIC Servizi S.r.l., Milan, Italy, 17, pp. 891-896.

Popović, V. (2010): Agro-technical and agro-ecological influence on the production of wheat, maize, and soybean seeds. Doctoral dissertation, University of Belgrade, Faculty of Agriculture, Zemun, 1-145.

Quinn, R. M. (1999): Kamut ${ }^{\circledR}$ : ancient grain, new cereal. In: "Perspectives on new crops and new uses" (Ed. Janick J.). Alexandria: ASHS Press, pp. 182-183.

Rajičić, V., Popović, V., Perišić, V., Biberdžić, M., Jovović, Z., Gudžić, N., Mihailović, V., Čolić, V., Đurić, N. Terzić, D. (2020). Impact of Nitrogen and Phosphorus on Grain Yield in Winter Triticale Grown on Degraded Vertisol. MDPI-Agronomy, 10,757; doi: 10.3390/agronomy10060757

Rakić, S., Janković, S., Demin, M., Bucalo, D., Maslovarić, M. (2012a): Quality and condition of wheat grain (Triticum spp.) during storage. Biotechnology in Animal Husbandry, 28 (3), 595-602. 
Rakić, S., Janković, S., Krivokapić, M., Jovanović, R., Ikanović, J. (2012b): Grain quality and status of oats (Avena sativa L.) during storage. Biotechnology in Animal Husbandry, 28 (4), 863-871.

Terzić, D., Popović, V., Malić, N., Ikanović, J., Rajičić, V., Simic, D., Lončarević, V. (2019): Effects of long-term fertilization on yield of siderates and organic matter content of the soil in the process of recultivation. The Journal of Animal and Plant Sciences, 29 (3): 790-795.

Ugrenović, V. (2013): Uticaj vremena setve i gustine useva na rastenje i razviće, morfološke osobine i prinos pšenice krupnika (Triticum spelta L), doktorska disertacija, Poljoprivredni fakultet, Beograd.

Ugrenović, V., Bodroža Solarov, M., Pezo, L., Đisalov, J., Popović, V., Marić, B., Filipović, V. (2018): Analysis of spelt variability (Triticum spelta L.) grown in different conditions of Serbia by organic conditions. Genetika, 50 (2): 635-646.

Xia, S. K., Chen, L., Liang, J. Q. (2007): Enriched selenium and its effects on growth and biochemical composition in Lactobacillus bulgaricus. J. Agric. Food Chem., 55: 2413-2417, DOI: 10.1021/jf062946j.

Yu, L., Perret, J., Davy B., Wilson J., Melby Cl. (2002): Antioksidan properties of cereal products. Journal of Food Science. 67: 2600-2603. 